\title{
Geochemical scaling potential simulations of natural organic matter complexation with metal ions in cooling water at Eskom power generation plants in South Africa
}

\author{
GO Bosire* JC Ngila' and Thabo TI Nkambule ${ }^{2}$ \\ 'Department of Applied Chemistry, University of Johannesburg, PO Box 17011, Doornfontein 2028 Johannesburg, South Africa \\ ${ }^{2}$ Nanotehnology and Water Sustainability Research Unit, College of Science, Engineering and Technology, University of South Africa, South Africa
}

\begin{abstract}
The modified database in the $\mathrm{pH}$, redox equilibrium calculations code (PHREEQC) with a Tipping and Hurley database (T_H.DAT) coupled with the Windermere's humic acid model (WHAM) was used to simulate scale formation potential in cooling water circuitry, at Eskom power generating stations in South Africa. This study reports a semi-empirical simulative approach in which organic matter fractions, metals and anions in raw and cooling water were used as modelling experimental inputs. By using the saturation index profiles of $\mathrm{Ca}^{2+} / \mathrm{Mg}^{2+}$ with fulvic acid in a modified Tipping and Hurley (T_H.DAT) database, fulvate complex species such as CaFulvate, MgFulvate, and geochemical modelling predictions, mineral phases that potentially precipitate are discussed. Speciation calculations showed that the increase in fulvic acid levels decreased saturation indices of scaling metal phases due to reduced levels of $\mathrm{Ca}^{2+}$ and $\mathrm{Mg}^{2+}$ in the water. Furthermore, if the concentrations of fulvic acid are known, semi-empirical calculations using the geochemical PHREEQC code with a modified T_H.DAT are possible. Consequently, mineral phase equilibria outputs may give an indication of how the $\mathrm{pH}$ and temperature is to be manipulated to optimally predict and control the incidence of scaling.
\end{abstract}

Keywords: mineral phases, PHREEQC, saturation indices, Tipping and Hurley database

\section{INTRODUCTION}

Eskom, a power-generating company in South Africa, draws water for cooling turbines mainly from surface water systems. This type of water has high levels of dissolved solids, mainly organic and inorganic compounds (Pather, 2004). The interaction of the various chemical components may produce ions, compounds in solid or liquid phases and complexes. Comprehensive studies have shown that when such water goes through industrial pipes, solid mineral phases, known as scale, form (Zhang et al., 2013, Rosenberg et al., 2012), which compromises water flow efficiency. One challenge, therefore, is the fact that there are dynamic chemical interactions of the water components that lead to changing phases because of changing physico-chemical parameters (such as conductivity, alkalinity and $\mathrm{pH}$ ) (Brunner, 2014). Current research has shown that natural organic matter (NOM) influences chemical interactions of certain species in natural water. Studies on NOM range from its characterization and fractionation to complexing capacity and degradation. Research has revealed that NOM is a complex matrix with transphilic, hydrophobic and hydrophilic components (Filloux et al., 2012; Zhou et al., 2014).

Evidence indicates that cooling water constituents change as it is recycled over and over, which in turn affects the stability of the NOM-metal complexes and consequently results in changed solubility of the salts present (Hoch et al., 2000, Tipping, 2002). What is not clear is how the fractions of NOM in water and their complexation reaction capacities

\footnotetext{
To whom all correspondence should be addressed. e-mail: orinajeff@gmail.com

Current address: Machakos University, PO Box 136-90100, Machakos County, Kenya
}

Received 6 December 2014, accepted in revised form 26 September 2018. for $\mathrm{Ca}^{2+}$ and $\mathrm{Mg}^{2+}$ influence pipe scaling. This study sought to provide some answers to this and related questions through geochemical modelling and speciation simulations. One shortcoming, however, is that most geochemical codes do not have comprehensive databases that describe complexation reactions, particularly those that describe NOM fractions. The current study describes (i) the modification of the Tipping and Hurley database with the Windermere Humic Acid Model (WHAM) database (T_H.DAT) to incorporate humate and fulvate equilibrium definitions with $\mathrm{Ca}$ and $\mathrm{Mg}$ ions, and (ii) speciation calculations generating saturation indices of scaling mineral phases.

Successful modification of the T_H.DAT was achieved by coding $\log k$ values for $\mathrm{Mg}$ and Ca equilibrium reactions with predominant NOM fractions (fulvates and humates) into it. Stability definitions for these reactions were obtained from risbergfa13.vdb, shmgeneric10.vdb, genericha08.nic and genericfa08.nic databases in Visual MINTEQ version 3.1.1. All these databases are based on the NICA-Donnan model (NIC) (Milne et al., 2003, Koopal et al., 2005, Christensen et al., 1998) and the Stockholm humic model (SHM) (Gustafsson, 2001; Gustafsson and Berggren, 2005; Pourret et al., 2007). To obtain the desired outputs, the modified T_H.DAT was set as the default database in the PHREEQC program and thereafter used for speciation simulations. The simulation mixture comprised of scaling cations $\left(\mathrm{Ca}^{2+}\right.$ and $\left.\mathrm{Mg}^{2+}\right)$ and anions $\left(\mathrm{SO}_{4}^{2-}, \mathrm{Cl}^{-}, \mathrm{NO}_{3}^{-}\right)$ defined as SOLUTION_SPECIES. The carbonate concentration was considered as alkalinity measured as $\mathrm{HCO}_{3}^{-}$which was also defined in the SOLUTION_SPECIES block. Fulvate-2 and Humate-2, previously defined as SOLUTION_MASTER_ SPECIES in the Tipping and Hurley's WHAM model (2003), generated MgFulvate, CaHumate and MgHumate in addition to other mineral phases. Saturation indices (SI) were calculated using adjusted PHREEQC database (F_H.DAT) to show mineral dissolution or precipitation. 


\section{MATERIALS AND METHODS}

The concentrations of the metal ions were determined by inductively coupled plasma optical emission spectrometry (ICP-OES) (Spetro Arcos, with a Cetac ASX-520 autosampler) and the anions in the samples by ion chromatography, IC (ICS - 1500 model) using the Dionex IonPac AS914 (Analytical $4 \times$ $250 \mathrm{~mm}$ ) column, and the Dionex IonPac AG14 (Guard $4 \times 50$ $\mathrm{mm})$ column. The LC-OCD analyses were carried out on DOCLabor LCOCD instrument (Mode 8, Version of 2012-08-27). Fluorescence EEM measurements were conducted using the Aqualog fluorescence instrument (Horiba, New Jersey, USA). The speciation and saturation index simulation results were generated by modelling software, PHREEQC, with an interactive interphase, and a modified Tipping and Hurley $\left(\mathrm{T}_{-} \mathrm{H}\right)$ database.

\section{Sampling and sample preparation}

Water samples were collected in $1000 \mathrm{~mL}$ sampling bottles from 4 sampling sites (A: raw, B: clarifier, C: inlet and D: outlet cooling water) (Fig. 1) in the cooling water processes at Kriel and Lethabo power stations. The samples were transported to the laboratory and immediately refrigerated at $4^{\circ} \mathrm{C}$.

\section{Instrumentation}

\section{pH and conductivity analysis}

The $\mathrm{pH}$ and conductivity measurements of all samples were done using $\mathrm{pH} /$ conductivity meter Model 3540 (Jenway Inc, Essex, CM6 3LB, England) and calibrations performed with calibrating standard solutions $\left(\mathrm{pH}=4.01\right.$ and 7.00 at $\left.25^{\circ} \mathrm{C}\right)$. The accuracy of the $\mathrm{pH}$ measurements was $\pm 0.05 \mathrm{pH}$ units. Triplicate readings of each analysis were taken and then the average value used for the analysis.

\section{ICP-OES and ion chromatography analyses}

All the samples were filtered through $0.45 \mu \mathrm{m}$ syringe filters before analysis. The anions in the samples were analysed by ion chromatography (IC). A mixture of $3.5 \mathrm{mM}$ sodium carbonate $\left(\mathrm{Na}_{2} \mathrm{CO}_{3}\right)$ and $1.0 \mathrm{mM}$ sodium bicarbonate $\left(\mathrm{NaHCO}_{3}\right)$ was used as the eluent.

\section{LC-OCD analysis}

Dissolved organic carbon (DOC) was determined chromatographically using the DOC-labor LC-OCD technique and correlated with the absorbance at $254 \mathrm{~nm}$ for specific ultraviolet absorbance (SUVA). Using this technique, a mobile phase was delivered with an HPLC pump (S-100, Knauer, Berlin, Germany) at a flow rate of 1.1 $\mathrm{mL} \cdot \mathrm{min}^{-1}$ to an autosampler (MLE, Dresden, Germany, $1 \mathrm{~mL}$ injection volume) and the chromatographic column (a weak polymethacrylate cation exchange column, $250 \mathrm{~mm} \_20 \mathrm{~mm}$, TSK HW 50S, 3000 theoretical plates, Toso, Japan). Before chromatographic separations, water samples were passed through an in-built $0.45 \mu \mathrm{m}$ membrane filter to remove particulate organic matter. Systematically, the organic carbon detector comes after the non-destructive, fixed wavelength UV-detection (UVD $254 \mathrm{~nm}$, type S-200, Knauer, Berlin, Germany). This LC-OCD procedure was described by Huber

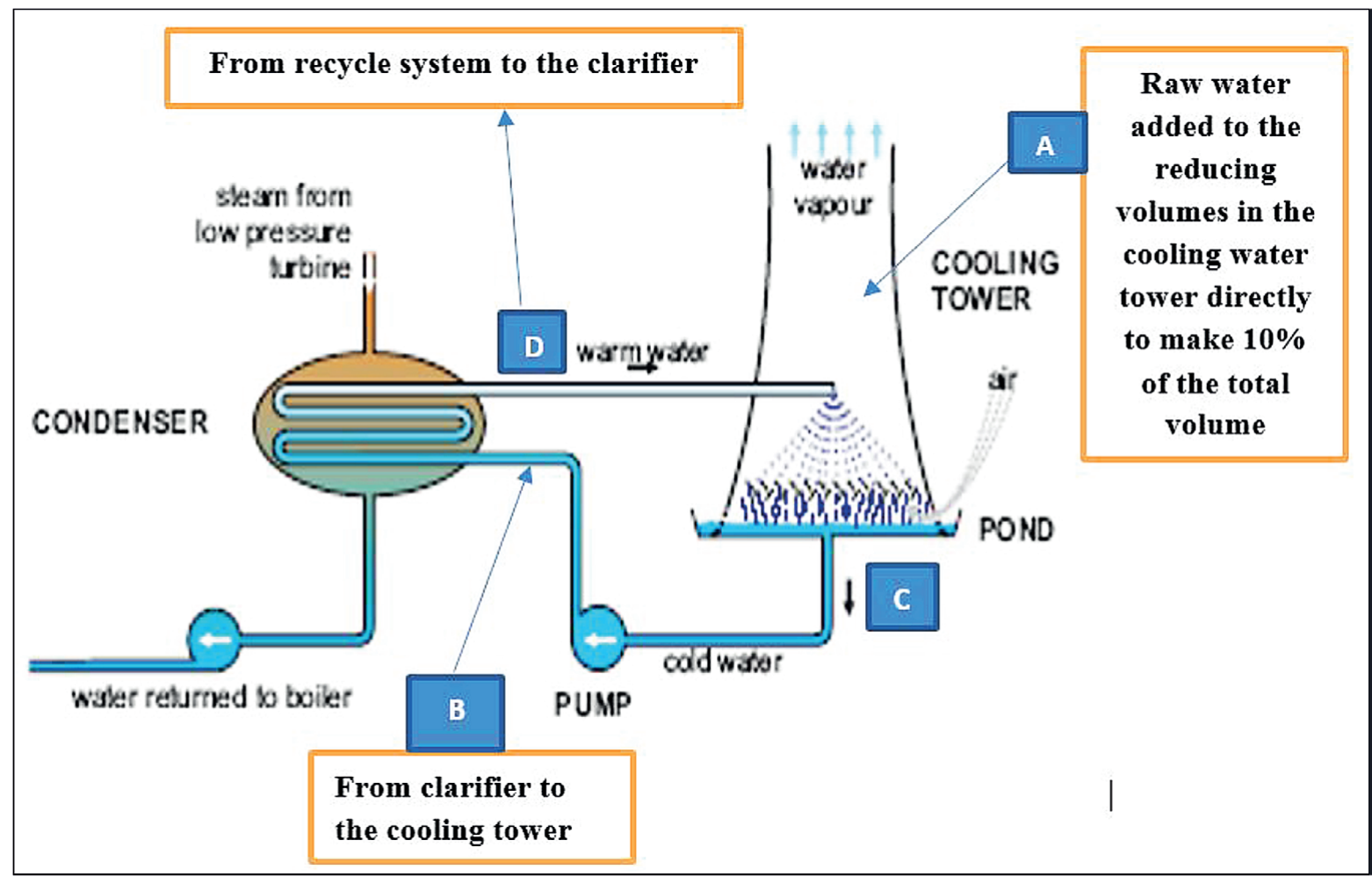

Figure 1

The cooling water process at a typical power generating station at Eskom, South Africa. The symbols, A-D indicate the sampling sites: $A$ - raw water; $B$-cooling water inlet; $C$ - cooling water at outlet; $D$-clarifier 
et al. (2011). The procedure includes acidification of the water samples at the inlet of the OCD (at a flow rate of $0.2 \mathrm{~mL} \cdot \mathrm{min}^{-1}$ ) to convert carbonates to carbonic acid. This initial stripping process removes all inorganic carbon. Subsequent steps involving analysis of organic carbon were done by wet oxidation. The oxygen required to oxidize DOC comes from water by a process called radiolysis of water at $185 \mathrm{~nm}$. This way, most compounds including fluoro-organic compounds, were oxidized. The organic carbon detector (OCD) calibration was based on potassium hydrogen phthalate. In this case, the carbon mass was used to calibrate the OCD and its extinction coefficient, $\varepsilon=1.683 \times 10^{-3} \mathrm{~L} \cdot \mathrm{mol}^{-1} \cdot \mathrm{cm}^{-1}$, used to calibrate the UVD (Huber et al., 2011).

\section{Fluorescence excitation-emission matrices (FEEM)}

Fluorescence emission excitation matrices (FEEMs) were collected using a Horiba AquaLog Spectrometer (Jvon, New Jersey, USA). No pre-treatment of the samples was applied. Maintaining a common $\mathrm{pH}$ between samples ensures that the fluorescence characteristics of the acidic functional groups in humic molecules remain constant. For this reason, all the samples were adjusted to a $\mathrm{pH}$ of 7 . Collection of intensity values was at $10 \mathrm{~nm}$ increments within excitation-emission ranges of 250-450 $\mathrm{nm}$ and $300-600 \mathrm{~nm}$, respectively. Scan rate was set to $600 \mathrm{~nm} \cdot \mathrm{min}^{-1}$, slit width was set to $10 \mathrm{~nm}$ and photomultiplier tube voltage was set to $775 \mathrm{~V}$. Type 1 water at $\mathrm{pH}$ of 7 was used as a blank solution. The fluorescence spectrometer used a xenon lamp excitation source and the emission at longer wavelengths was detected at $0.3 \mathrm{~nm}$ steps. Further to this, inner-filter correction and Rayleigh scattering was applied to the data.

In this study, fluorescence was carried out under dilute sample conditions, which follows the equation:

$$
F \propto I_{o} * A b s_{O V} * \emptyset F
$$

where $I_{O}$ is the exciting light intensity, $A b s_{O V}$ is the number of quanta absorbed in the overlap region (OV) and $\varnothing F$ is the ratio of the quanta emitted to the quanta absorbed. The spectra obtained were corrected for instrumental and sample dependent spectral anomalies such as the inner-filter effects associated with sample absorbance of excitation and emission (Rayleigh scattering). Appropriately, spectral data can be compared to standard data and regions in literature and qualitative and quantitative NOM details will be drawn. Figure 2 shows some literature-based spectral regions using defined excitation and emission wavelength boundaries (Gilmore et al., 2003).

Peaks at shorter excitation wavelengths $(280 \mathrm{~nm})$ and longer emission wavelengths (> $380 \mathrm{~nm}$ ) are associated with humic acid-like compounds. This NOM-related spectral information lacks capabilities of quantifying multiple broad-shaped EEM peaks. Chen et al. (2003) postulated that integration beneath EEMs within selected regions would represent cumulative fluorescence responses of NOM with similar properties. This technique shows that the volume $\Phi$ beneath a region said to be $i$ of an EEM be calculated by Eq. 2:

$$
\Phi_{i}=\int_{e x}^{x} \int_{e m}^{x} \mathrm{I}\left(\lambda_{e x} \lambda_{e m}\right) d \lambda_{e x} d \lambda_{e m}
$$

where $d \lambda_{e m}$ is the excitation wavelength interval (taken as $10 \mathrm{~nm}), d \lambda_{e m}$ is the emission wavelength interval (taken as $0.5 \mathrm{~nm})$, and $I\left(\lambda_{e x} \lambda_{e m}\right)$ is the fluorescence intensity at each excitation-emission wavelength pair. The values of $\Phi_{i}$ can be normalized to a DOC concentration of $1 \mathrm{mg} \cdot \mathrm{L}^{-1}$ for comparison of EEMs from different sources of NOM (Zhou et al., 2005).

Via ParaFac modelling, differences in the spectral slopes have been related to the proportional contribution of UV-B

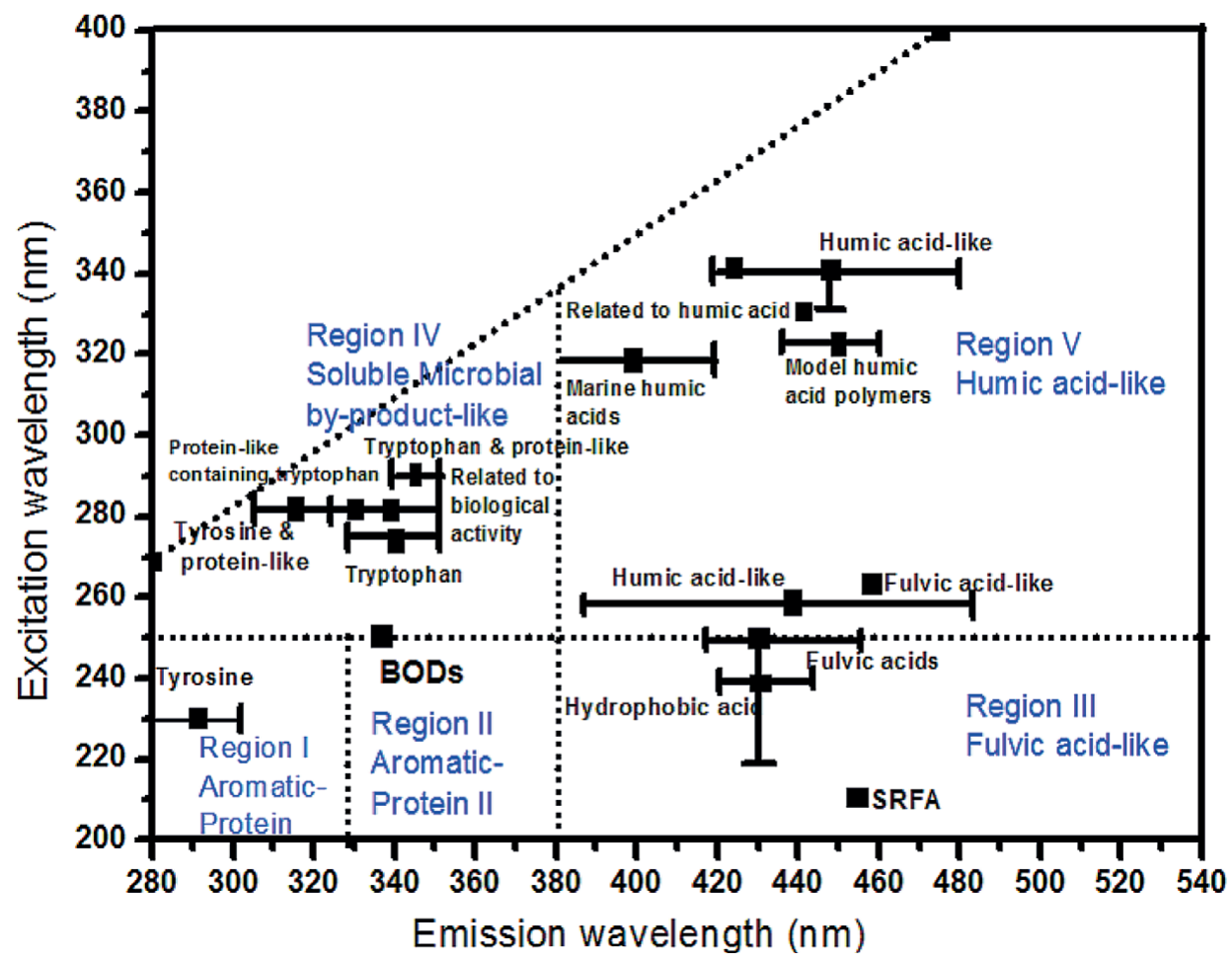

Figure 2

FEEM spectral regions based on reported definite excitation (Ex) and emission (Em) wavelengths (adapted and redrawn from Gilmore et al., 2003) 
absorption coefficients to the CDOM spectra which, as literature suggests, is dependent on the different CDOM sources in natural waters (Guéguen et al., 2011). This model factorizes a spectral matrix into three sub-matrices using the same number of factors in Eq. 3. Therefore, the F-EEM data is broken down into a set of tri-linear terms and a residual array.

$$
X_{i j k}=\sum_{f=1}^{F} a_{i f} b_{f j} c_{k f}+\varepsilon_{i j k} i=1, \ldots, k j=1, \ldots, k=1, \ldots, k
$$

Equation 3 is the ParaFac equation in which $X_{i j k}$ is the fluorescence intensity of emission sample $I$ at the $j^{\text {th }}$ emission wavelength and the $k^{\text {th }}$ excitation wavelength for ParaFac model with $F$ number of components. The terms $a, b$, and $c$ represent the concentration, emission spectra, and excitation spectra, respectively, of the different fluorophores. The $a_{i f}$ term is directly proportional to the concentration of the $f^{\text {th }}$ analyte of the $i^{\text {th }}$ sample, while $b_{f j}$ and $c_{k f}$ are scaled estimates of the emission and excitation spectra at wavelengths $j$ and $k$, respectively, for the $f^{\text {th }}$ analyte. The $\varepsilon_{i j k}$ term represents any unexplained signal resulting from residual noise or un-modelled variability (Gentry-Shields et al., 2013). Evidence suggests that with the ParaFac model, four fluorescent components are identifiable: a protein-like component, soluble microbial by-product-like component, non-humic-like component and fulvic-like component (Guo et al., 2012).

\section{Modelling using PHREEQC-Interactive}

The geochemical code, PHREEQC, was used to calculate the aqueous speciation and saturation indices of different mineral phases. The phases included aragonite, calcite, gypsum, magnesite, anhydrite and dolomite. During the assessment of the impact of humic substances on speciation and saturation indices, PHREEQCI databases were modified before calculations. PHREEQC Version 3 implements many types of aqueous models, among them the following: ion-association aqueous models (the Lawrence Livermore National Laboratory model and WATEQ4F), a Pitzer specific-ion-interaction aqueous model, and the SIT (Specific ion Interaction Theory) aqueous model (Parkhurst and Appelo, 2013). Using these aqueous models, PHREEQC is able to carry out the following simulations: ion speciation (output including saturation indices), batch-reaction modelling (including equilibrium phases), surface complexation and ion exchange, reaction (addition/removal of specified elements), mixing waters and changing temperature, transport modelling, advection with reactions with and without dispersion, and inverse modelling, and can calculate reactions that account for changes in composition of water along a flow path (Parkhurst and Appelo, 2013).

\section{Database modification}

The specific database used in PHREEQC for the simulations is based on various approaches such as (i) the ion association approach (these include phreeqc.dat, wateq4f.dat, minteq.dat, llnl.dat, iso.dat and phreeqd.dat (Charlton and Parkhurst, 2011); (ii) the diffusion coefficients: multicomponent diffusion, specific conductance; iii) molar volumes for calculation of density; and iv) the Pitzer specific interaction approach - Pitzer.dat. Various databases are based on the equations that define activity coefficients for model solutions and reactions and are discussed in this section. For example, the Lawrence Livermore National Laboratory aqueous model (LLNL) uses the following expression (Eq. 4) for the log (base 10) of an activity (Charlton and Parkhurst, 2011):

$$
\log \gamma=\frac{A \gamma^{z^{2} \sqrt{I}}}{1+a_{\mathrm{i}}^{0} B_{\gamma} \sqrt{\mathrm{I}}}+B I
$$

where $A_{\gamma}$ is the Debye-Hückel $A$ parameter corresponding to -dh_a, $B_{\gamma}$ is the Debye-Hückel $B$ parameter corresponding to -dh_b $B$ is the Debye-Hückel $B$ - dot parameter corresponding to -bdot, $a_{\mathrm{i}}^{0}$ is the hard-core diameter, which is specific to each aqueous species, and $I$ is the ionic strength. The LLNL AQUEOUS_MODEL_PARAMETERS data block defines $A_{\gamma}$, $B_{\gamma}$ and $B$ as functions of temperature (Charlton and Parkhurst, 2011).

The Pfizer database is based on the Pfizer activity coefficients. Equation 5 shows the expression for a Pitzer parameter, $P$ with $T$ as the temperature in Kelvin, and $T_{r}$ as the reference temperature ( $298.15 \mathrm{~K})$. If less than 6 parameters are defined, the undefined parameters are assumed to be zero. When modifying a Pitzer aqueous interaction parameter, care is needed to ensure thermodynamic consistency among all the parameters. If the same type of parameter with the same set of species is redefined, even if the order of the species is different, then the previous definition is removed and replaced with the new definition (Charlton and Parkhurst, 2011).

$$
\begin{array}{r}
P=A_{0}+A_{1}\left(\frac{1}{T}-\frac{1}{T_{r}}\right)+\mathrm{A}_{2} \ln \left(\frac{T}{T_{r}}\right)+A_{3}\left(T-T_{r}\right) \\
+A_{4}\left(T^{2}-T_{\mathrm{r}}^{2}\right)+A_{5}\left(\frac{1}{T^{2}}-\frac{1}{T_{r}^{2}}\right)
\end{array}
$$

Carefully, therefore, the humate and fulvate thermodynamic definitions were incorporated into a Tipping and Hurley database with a WHAM (T_H.DAT) (Tipping, 2002), which defines the LLNL and the Pfizer databases. Table 1 shows the $\log k$ values for equilibrium phase equations of the reactions incorporated into the T_H.DAT database together with their stability constants, all drawn from visual MINTEQ v 3.1.1. For these reactions, the phases were defined as SOLUTION_SPECIES in T_H.DAT.

The simulation mixture comprised of scale-forming cations $\left(\mathrm{Ca}^{2+}\right.$ and $\left.\mathrm{Mg}^{2+}\right)$ and anions $\left(\mathrm{SO}_{4}^{2-}, \mathrm{Cl}^{-}, \mathrm{NO}_{3}^{-}\right)$defined as SOLUTION_SPECIES. The carbonate concentration was considered as alkalinity measured as $\mathrm{HCO}_{3}{ }^{-}$which was also defined in SOLUTION_SPECIES block. Fulvate- 2 and Humate-2, have been previously defined as SOLUTION_ MASTER_SPECIES in the Tipping and Hurley WHAM model (2003). The modified T_H.DAT incorporates $\log k$ values from risbergfa13.vdb, shmgeneric10.vdb, genericha08.nic and genericfa08.nic databases in visual MINTEQ version 3.1. These values define the equilibrium phase equations of NOM (humic and fulvic acid) with $\mathrm{Mg}^{2+}$ and $\mathrm{Ca}^{2+}$ that give rise to CaFulvate, MgFulvate, CaHumate and MgHumate (Fig. 3).

\begin{tabular}{|l|l|l|}
\hline \multicolumn{3}{|c|}{ TABLE 1 } \\
Equilibrium phase equations defined in T_H.DAT as \\
SOLUTION_SPECIES \\
using the NICA-Donnan visual MINTEQ \\
\hline Phase & Equilibrium reaction & Log k \\
\hline \#CaFulvate & $\mathrm{Ca}^{+2}+$ Fulvate $^{-2}=$ CaFulvate & -3 \\
\hline \#MgFulvate & $\mathrm{Mg}^{+2}+$ Fulvate $^{-2}=$ MgFulvate & -2.4 \\
\hline \#CaHumate & $\mathrm{Ca}^{+2}+$ Humate $^{-2}=$ CaHumate & 0.43 \\
\hline \#MgHumate & $\mathrm{Mg}^{+2}+$ Humate $^{-2}=$ MgHumate & 0.60 \\
\hline
\end{tabular}




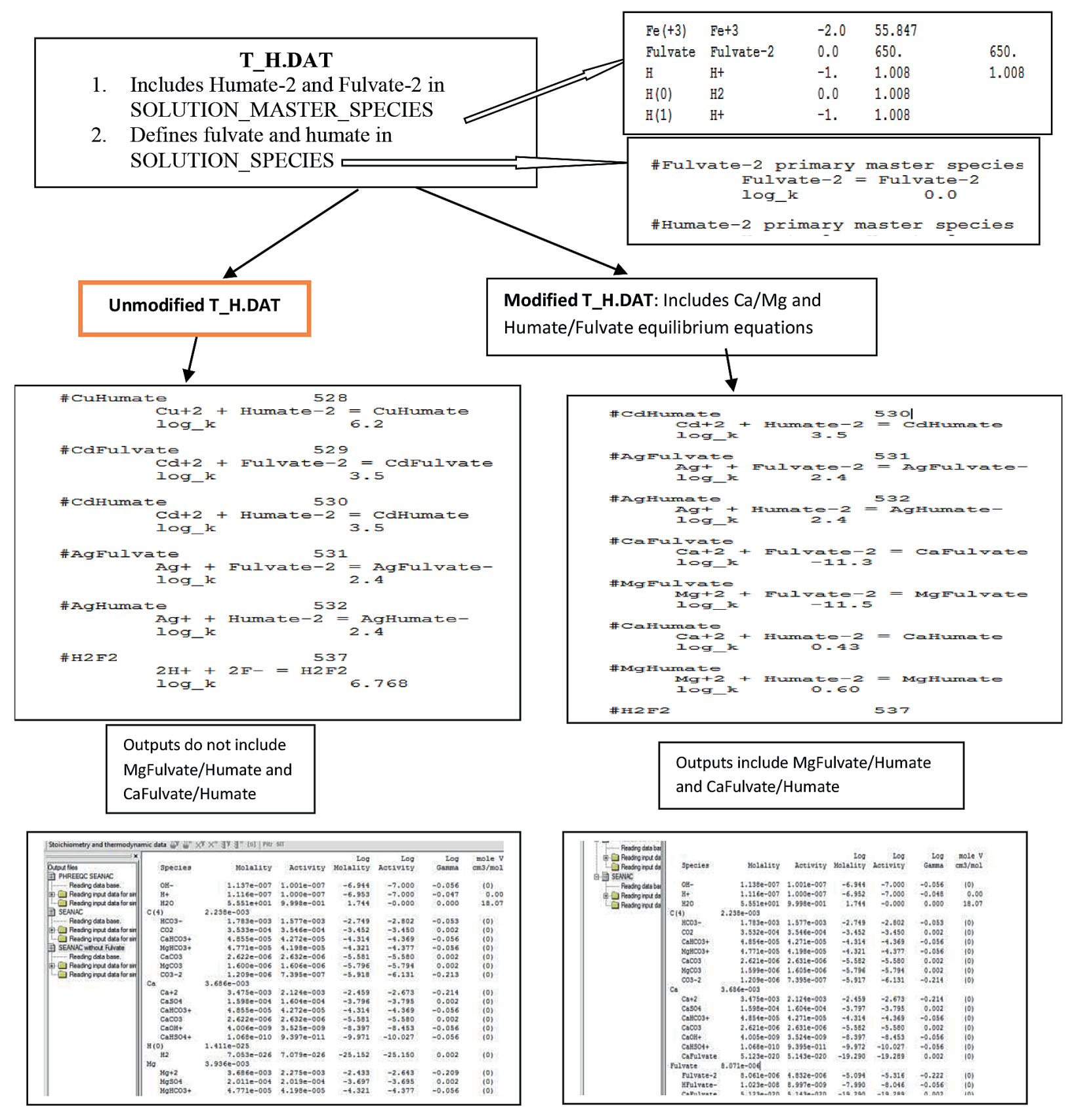

Figure 3

Modification of the Tipping and Hurley database with WHAM (T H.DAT) to include humates and fulvates. The speciation outputs of equilibrium reaction definitions in Table 1 are shown under modified T-H.DAT.

\section{Mineral saturation}

The $\mathrm{pH}$, alkalinity, metal cations and anions were modelled together with organic components (fulvates) using a fulvateadjusted T_H database. The input-output geochemical execution processes on the PHREEQC code are summarised in Fig. 4. To show mineral dissolution or precipitation, saturation indices (SI) were calculated. Herein, a general reaction (Eq. 6), describes super-saturation which is the key parameter that determines precipitation. The saturation ratio $(S)$ is described as the ratio of the ionic activity product (IAP) to the equilibrium constant $(K s)$ (Eq. 7).

$$
A^{-}+B^{+}=A B+g+l
$$

where $\mathrm{A}^{-}$is the anion being equilibrated $\left(A^{-}=\left(\mathrm{SO}_{4}^{2-}, \mathrm{Cl}^{-}, \mathrm{NO}_{3}^{-}\right.\right.$, $\left.\mathrm{CO}_{3}^{2-}, \mathrm{PO}_{4}^{3-}\right), B^{+}$is the metal cation, $A B$ is the mineral phase formed and $g$ and $l$ are any gas or liquid phases, respectively.

$$
S=\frac{I A P}{K_{S}}=\frac{\left[A^{-}\right]\left[B^{+}\right]}{K_{S}}
$$

A value of $S<1$, indicates an under-saturated solution, $S=1$ shows a solution in equilibrium with the solid, while $S>1$ shows 


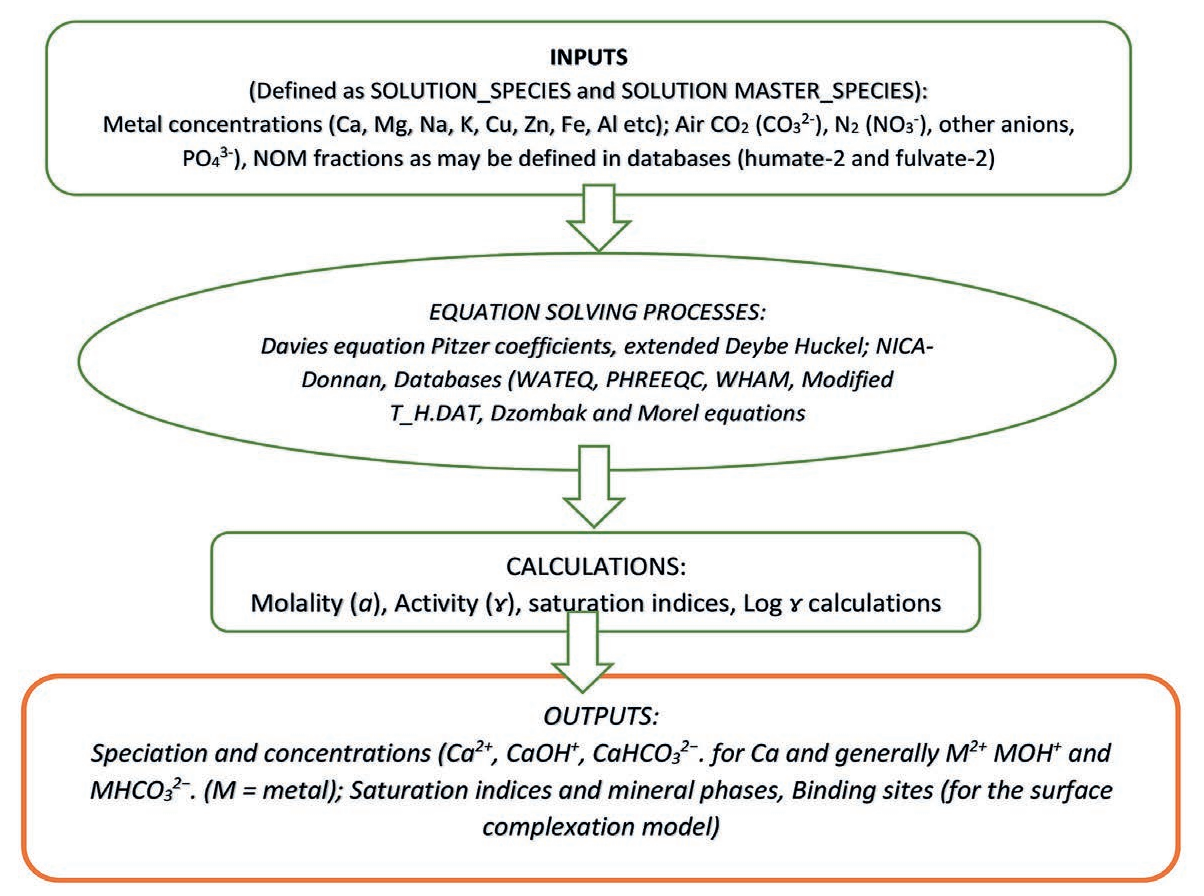

Figure 4

A scheme on geochemical modelling processes. The PHREEQCI processes with a modified $T_{-} H$ database typify these processes

a supersaturated solution, which leads to precipitation/scaling. Saturation indices $(\mathrm{SI})$ are defined as $\mathrm{SI}=\log _{10}(S)$, so that an equilibrium situation corresponds to $\mathrm{SI}=0$, and under-saturation and super-saturation shown by SI $<0$ and SI $>0$, respectively.

A very high or very low SI does not always indicate 'extreme' conditions but may merely be a mineral that is less reactive. From a geochemistry perspective, reactive minerals are those that dissolve in water or precipitate from water during the residence time in the water (Peters, 2009). A general flow scheme on geochemical modelling is given in Fig. 4.

\section{RESULTS AND DISCUSSION}

The FEEM spectral signatures, LC-OCD, IC, ICP-OES results together with speciation simulations are presented for raw, clarified and cooling water from Kriel (K) and Lethabo (L) power stations. This study focuses on raw and cooling water at the outlet point to explain potential scaling in water pipe circuitry. Using $\mathrm{pH}$ values (Table 2), alkalinity, alkaline earth metal cations $\left(\mathrm{Ca}^{2+}\right.$, $\left.\mathrm{Mg}^{2+}\right)$ and anions $\left(\mathrm{SO}_{4}^{2-}, \mathrm{Cl}, \mathrm{NO}_{3}^{-}, \mathrm{CO}_{3}^{2-}, \mathrm{PO}_{4}^{3-}\right.$ ), various temperature and NOM (fulvic acid) dependent simulations were carried out. The relatively similar raw water characteristics obtained in this study confirmed water use from the same source, the Vaal River. Fundamental characteristics of water, which were used as inputs in the PHREEQC simulations, are shown in Table 2.

\section{Characterization and quantification of NOM}

\section{Identification of humic substances}

The improved humic substances (HS) diagram (HS-diagram), reveals the aromatic character ( $x$-axis) of NOM fractions as a

\begin{tabular}{|c|c|c|c|c|c|c|c|c|}
\hline \multicolumn{9}{|c|}{$\begin{array}{l}\text { TABLE } 2 \\
\text { Main characteristics of raw and cooling water in the cooling water processes (CWPs) }\end{array}$} \\
\hline \multirow[t]{2}{*}{ Characteristic } & \multicolumn{4}{|c|}{ Lethabo Water } & \multicolumn{4}{|c|}{ Kriel Water } \\
\hline & Raw & Clarifier & Inlet & Outlet & Raw & Clarifier & Inlet & Outlet \\
\hline $\mathrm{pH}$ & 10.22 & 9.05 & 9.60 & 8.91 & 9.97 & 9.74 & 10.46 & 9.69 \\
\hline Conductivity $(\mathrm{S} / \mathrm{m})$ & 0.18 & 4.63 & 4.05 & 4.67 & 0.28 & 3.49 & 3.25 & 3.46 \\
\hline \multicolumn{9}{|c|}{ Common anions (IC) in mg. $\mathrm{L}^{-1}$} \\
\hline Fluoride & 0.60 & 2.11 & 2.07 & 2.31 & 0.65 & 2.60 & 1.15 & 3.06 \\
\hline Bromide & ND & 158.95 & 159.57 & 166.41 & ND & 47.42 & 43.85 & 41.75 \\
\hline Sulphate & 0.09 & 5.595 & 4.11 & 5.98 & 0.20 & 3.442 & 5.08 & 3.12 \\
\hline \multicolumn{9}{|c|}{ Scaling metals (ICP-OES/MS) in mg. $\mathrm{L}^{-1}$} \\
\hline $\mathrm{Ca}$ & 7.85 & 34.53 & 38.94 & 37.81 & 11.25 & 142.95 & 154.6 & 158.2 \\
\hline $\mathrm{Mg}$ & 15.46 & 212.1 & 231.9 & 236.0 & 17.41 & 97.43 & 111.9 & 115.3 \\
\hline $\mathrm{Ba}$ & 0.05 & 0.90 & 0.12 & 0.12 & 0.06 & 0.13 & 0.22 & 0.23 \\
\hline
\end{tabular}


function of their molecularity ( $y$-axis) (Fig. 5a). This diagram is a plot of the spectral absorption coefficient (SAC) to the organic carbon (OC) ratio (aromaticity) of a HS-fraction against its nominal molecular weight $\left(M_{n}\right)$ (Huber et al., 2011). Accordingly, the curved boundaries define the region where the humic substances are characterized. The humic substances area was developed using fulvic and humic acid characteristics of water samples from different sources discussed in Huber et al. (2011). As reported in Huber et al. (2011), the humic acid (HA) and fulvic acid (FA) standard (II) isolates of the International Humic Substances Society (IHSS) were used to calibrate the HS molecular weights, prior to all characterizations. In the current study, raw and cooling water samples from Kriel and Lethabo power stations, were characterized. The results obtained showed that raw, clarifier and cooling water (inlet and outlet) from Kriel (shown by K) and Lethabo (shown by L) consists mainly of pedogenic fulvic acids (Fig. 5a). The fulvic acid character increased in the order of $\mathrm{E}>\mathrm{A}>\mathrm{G}, \mathrm{B}$ and $\mathrm{C}>\mathrm{H}$ and $\mathrm{F}>\mathrm{D}$. The raw water data points $\mathrm{A}$ and $\mathrm{E}$, from Kriel and Lethabo, respectively, are close to each other in the HS-diagram (Fig. 5a). This confirms the common source of cooling water used at these Eskom power stations, i.e., the Vaal river. The FA reported in this study is in close agreement with data reported by Huber et al. (2011), regarding the characteristics on the HS-diagram FA obtained from the river Rhine, river Seine and Steinbach surface water (Huber et al., 2011). However, the FA obtained from our study differs from the FA reported by Huber et al. (2011) on data obtained for river Westend, Lake Sosa, Lake Galilee and Caspian Sea waters. This variation in results further reveals the difference in surface origin of the FA obtained in our study, which was predominant in the cooling water analysed in this study.

\section{Quantification of NOM fractions}

Natural surface waters exhibit 5 distinct peaks corresponding to LC-OCD elutes of different NOM fractions, namely: (i)

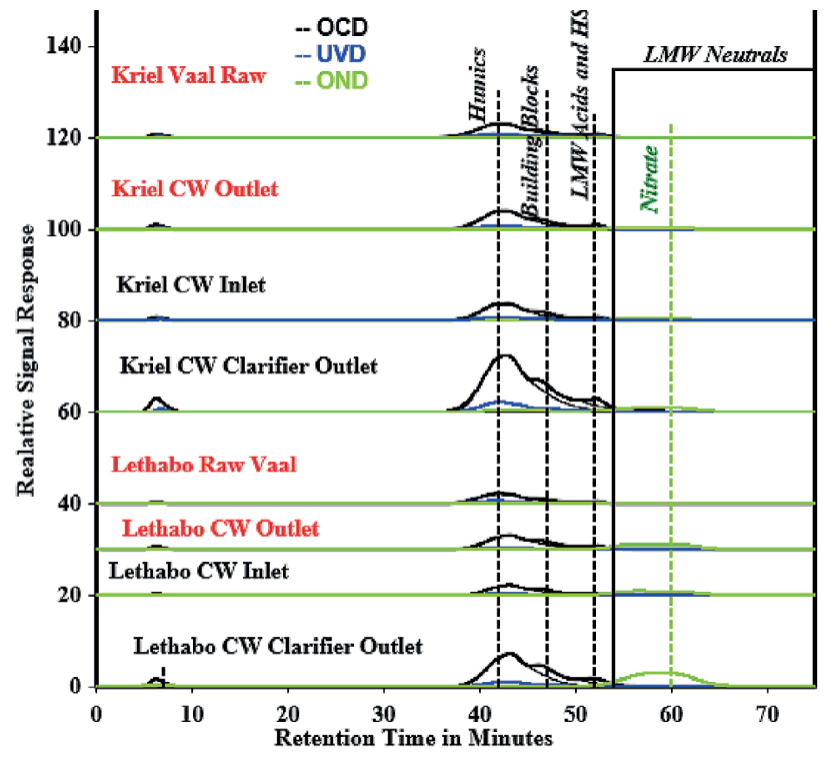

Figure $5 b$

Chromatograms of water in the CWP (Kriel and Lethabo power generating companies, South Africa), based on Fig. 5 a with fitted peaks for HS and fitted boundaries for non-humic matter.

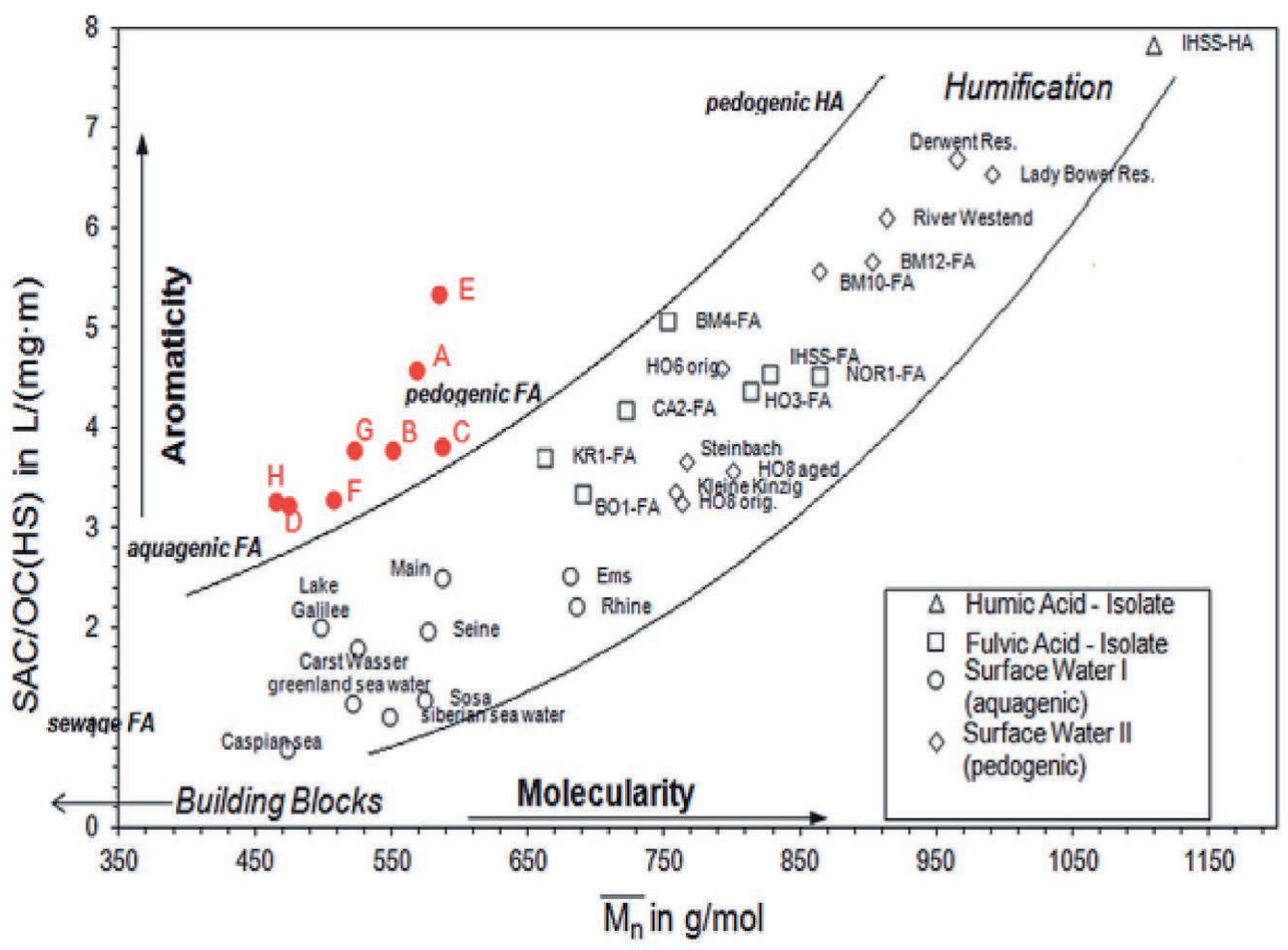

Figure $5 a$

The HS-diagram for humic fractions in cooling water samples from the Kriel (K) and Lethabo $(L)$ power stations. Aromaticity of aquatic humic substances is measured as the SAC/OC ratio, which is plotted against molecularity (Mn values (nominal molecular weights)). (A: K-Raw; B: K-outlet CW; C: K-inlet CW; D: K-clarifier; E: L-Raw; F: L-clarifier; G; L-inlet CW; H: L-outlet CW). The calibration water sources are adapted from by Huber et al., 2011. 
biopolymers; (ii) humic substances; (iii) building blocks; (iv) low molecular weight acids and (v) low molecular weight neutrals. The major components of the humic substances' fraction, the HA and FA elute at 43.4 and $46.7 \mathrm{~min}$, respectively (Huber et al., 2011). Fig. 3 b shows chromatograms corresponding to the NOM fractions analysed by LC-OCD.

Table 3 summarizes the LC-OCD quantitative results, based on the raw and cooling water samples from the two power stations. These results include the humic substances which were predominantly fulvic acid, shown in Fig. 5b. For all samples, the humic substances fraction quantities did not differ significantly with total dissolved organic carbon (DOC) $\left(r^{2}=0.01677, p<0.05\right.$, ANOVA). For example, the percentage HS concentration to the total DOC in the raw water was $88.4 \%$ and $89.5 \%$ for samples from Kriel and Lethabo power stations, respectively. Separately, a similar observation was made using cooling water, i.e., $87.8 \%$ and $83.5 \%$ for Kriel and Lethabo, respectively. However, the raw and cooling water HS fractions from the power stations differed significantly $\left(r^{2}=0.95, p<5\right.$, ANOVA $)$.

Table 3 also shows the SUVA values corresponding to the various samples. NOM is hydrophilic (HPI) if the specific $\mathrm{UV}$ absorbance at $\lambda_{254}$ (SUVA) value $<2$ (an indication of non humic substances), hydrophobic (HPO) with a SUVA value $>4$ (an indication of humic substances) and is transphilic (TPI, a mixture of both $\mathrm{HPO}$ and $\mathrm{HPI}$ ) if $2 \leq \mathrm{SUVA} \leq 4$. In the present study, the SUVA values of the water samples generally show that the nature of humic substances is highly aromatic. This is supported by the high percentage of HS in dissolved organic carbon (DOC). Similar studies have shown that surface water from different sources contains a NOM matrix comprising of transphilic, hydrophobic and hydrophilic compounds (Filloux et al., 2012, Zhou et al., 2014). The percentage of humic substances reported by Zhou et al. (2014) (84\%) agree with the LC-OCD results obtained in this study for the raw and cooling water processes (ranging from $80-90 \%$ ).

\section{FEEM characterization of NOM}

Typical FEEM spectra of cooling water used at the Kriel power station are presented in Fig. 6. Generally, the observed excitation (EX) and emission (EM) spectra for water samples confirmed intense fulvic acid and humic acid activities. These

\section{Figure 6}

Typical fluorescence excitation-emission matrices of raw water (a), clarified water (b) and cooling water (c). The $x$-axis shows the range of excitation (EX) wavelength (220-350 nm) and the y-axis shows the emission (EM) wavelength range $(220-610 \mathrm{~nm})$
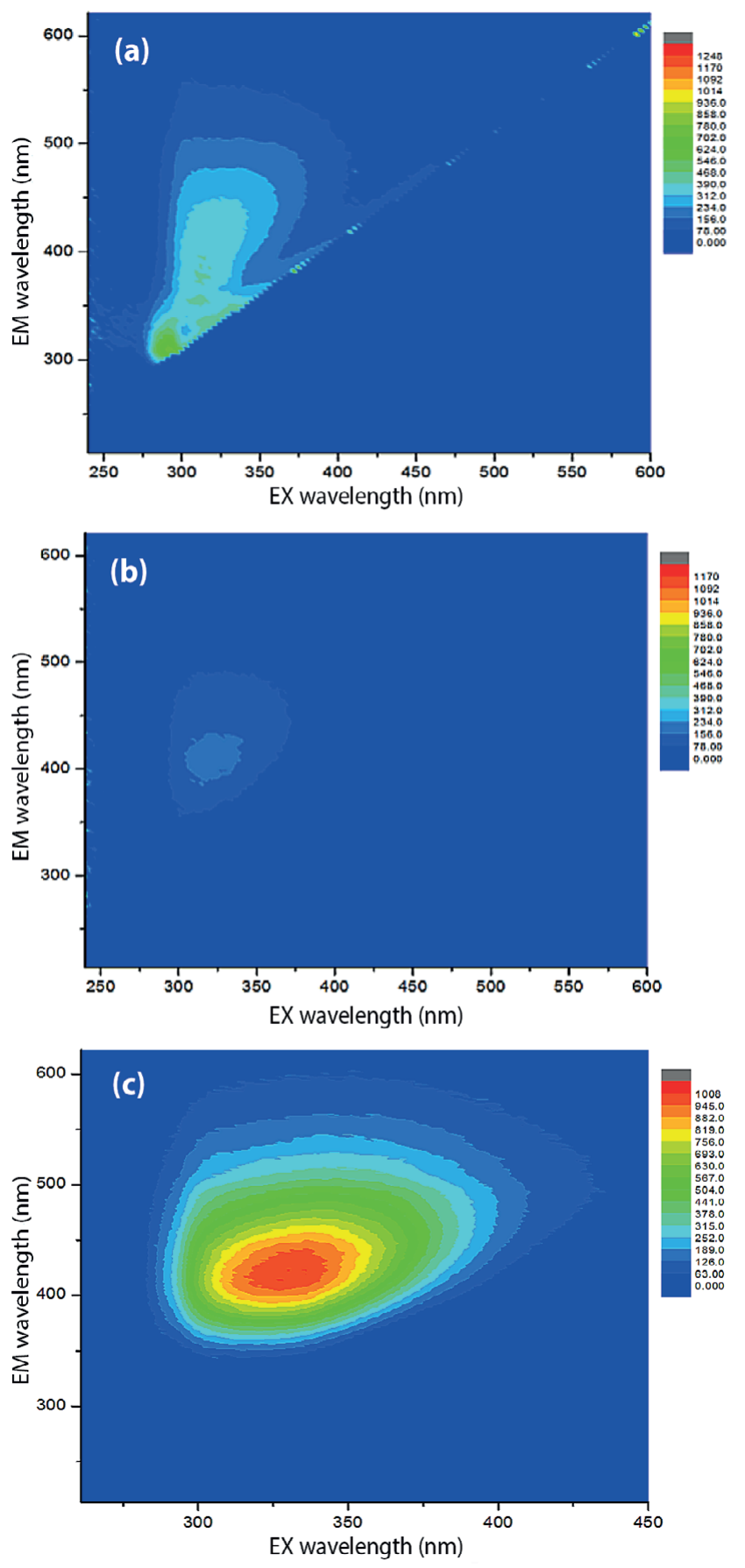

TABLE 3

Structural qualities of DOC and quantity of HS obtained with LC-OCD for Kriel (K) and Lethabo (L) power stations (*\% HS is calculated as (HS/DOC) $\times 100$; ${ }^{*} \mathrm{BBs}$ represents building blocks)

\begin{tabular}{|l|c|c|c|c|c|}
\hline Sample & DOC $\left(\mathbf{m g} \cdot \mathrm{L}^{-1}\right)$ & HS $\left(\mathbf{m g} \cdot \mathrm{L}^{-1}\right)$ & $\% * \mathrm{HS}$ & BBs as \% of HS & $\begin{array}{c}\text { SUVA SAC/DOC } \\
\left(\mathrm{L} \cdot \mathrm{mg}^{-1} \cdot \mathrm{m}^{-1}\right)\end{array}$ \\
\hline K-Raw & 5.934 & 5.244 & 88.4 & 12.548 & 5.18 \\
\hline K-CWO & 49.290 & 43.282 & 87.8 & 13.534 & 4.36 \\
\hline K-CWI & 47.023 & 40.574 & 86.3 & 15.769 & 4.40 \\
\hline K-Clarifier & 81.422 & 68.849 & 84.6 & 14.715 & 3.40 \\
\hline L-Raw & 4.022 & 3.599 & 89.5 & 10.475 & 6.58 \\
\hline L-Clarifier & 45.902 & 36.741 & 80.0 & 23.162 & 3.36 \\
\hline L-CWI & 25.830 & 21.714 & 84.1 & 18.698 & 4.97 \\
\hline L-CWO & 38.775 & 32.378 & 83.5 & 18.374 & 3.93 \\
\hline
\end{tabular}


observations complement the LC-OCD results presented in Table 3. The spectral signatures, as revealed by FEEM (Fig. 6), showed intense activity of HS at $\lambda_{E X} 250-290 / \lambda_{E M} 350-500 \mathrm{~nm}$, which further confirmed the predominance of fulvic acid in the NOM. The fulvic acid FEEM spectral regions have been reported elsewhere (Ahmed et al., 2014).

The observed raw and cooling water characteristics of NOM using LC-OCD and FEEM (found to be predominantly FA), and the quantitative measurements of HS (established to be FA), formed the basis of modelling discussions under the geochemical sub-heading. These include database modifications and the use of the PHREEQC code to include FA equilibrium reactions with selected cations.

\section{Geochemical modelling}

At ambient temperature $\left(25^{\circ} \mathrm{C}\right)$, the selected minerals (aragonite, dolomite, gypsum, calcite and magnesite) showed higher dissolution than precipitation (Fig. 7). These results were further simulated in an extended range of temperatures and the concentration of fulvic acid. Mineral phase modeling, using F_H.DAT, showed distinct saturation patterns. Saturation indices of selected phases are discussed in this article, including: the two polymorphs of calcium carbonate, namely; aragonite $\left(\mathrm{CaCO}_{3}\right)$ and calcite $\left(\mathrm{CaCO}_{3}\right)$, anhydrite $\left(\mathrm{CaSO}_{4}\right)$, gypsum $\left(\mathrm{CaSO}_{4} \cdot 2 \mathrm{H}_{2} \mathrm{O}\right)$, dolomite $\mathrm{CaMg}\left(\mathrm{CO}_{3}\right)_{2}$ and magnesite $\left(\mathrm{MgCO}_{3}\right)$. Both alkalinity defined as $\mathrm{HCO}_{3}^{-}$and sulphurcompounds in the form of $\mathrm{SO}_{4}^{2-}$ values were calculated as averages of raw and cooling water from Lethabo power station. From Fig. 7, the saturation levels revealed variations depending on the source of water. This conforms to what is expected as the cooling water evaporates. As the water gets recycled over and over, its components concentrate. The influence of temperature and concentration of humic substances on formation and saturation of these mineral phases are modelled in this section.

\section{Temperature-dependence mineral simulations}

Temperature simulations revealed 2 types of mineral phase occurrences: (i) mineral phases below and above the saturation lines (Fig. 8) showing under-saturation and supersaturation (calcite, aragonite, dolomite and magnesite), respectively; (ii) mineral phases showing under-saturation only (anhydrite and

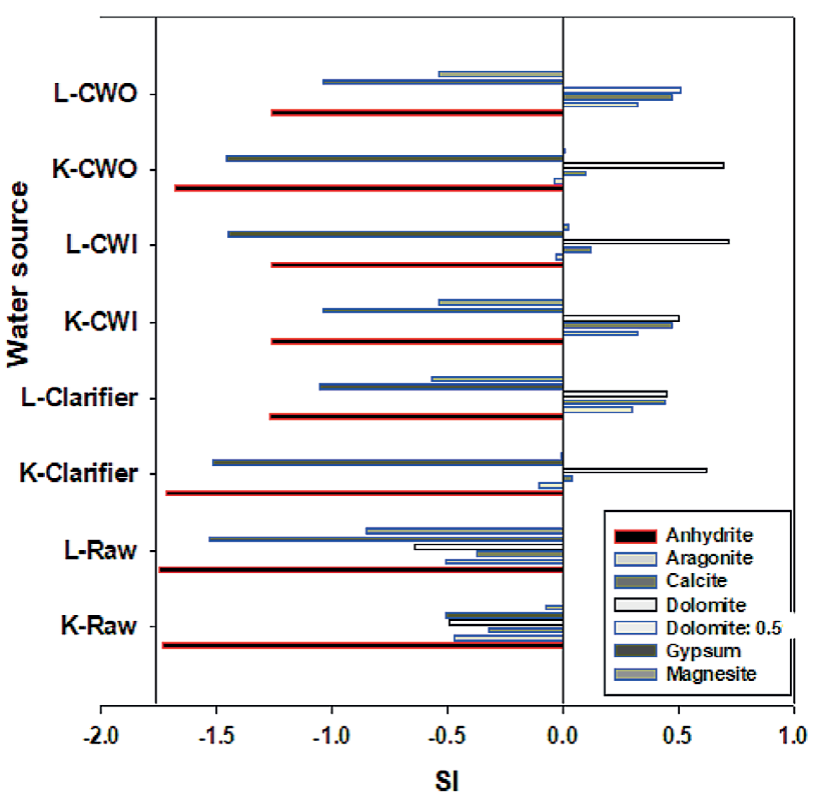

Figure 7

Saturation index levels of selected mineral assemblages using a modified F_H.DAT on the PHREEQCI code. Anhydrite, aragonite, calcite, dolomite, gypsum and magnesite represent selected mineral phases.
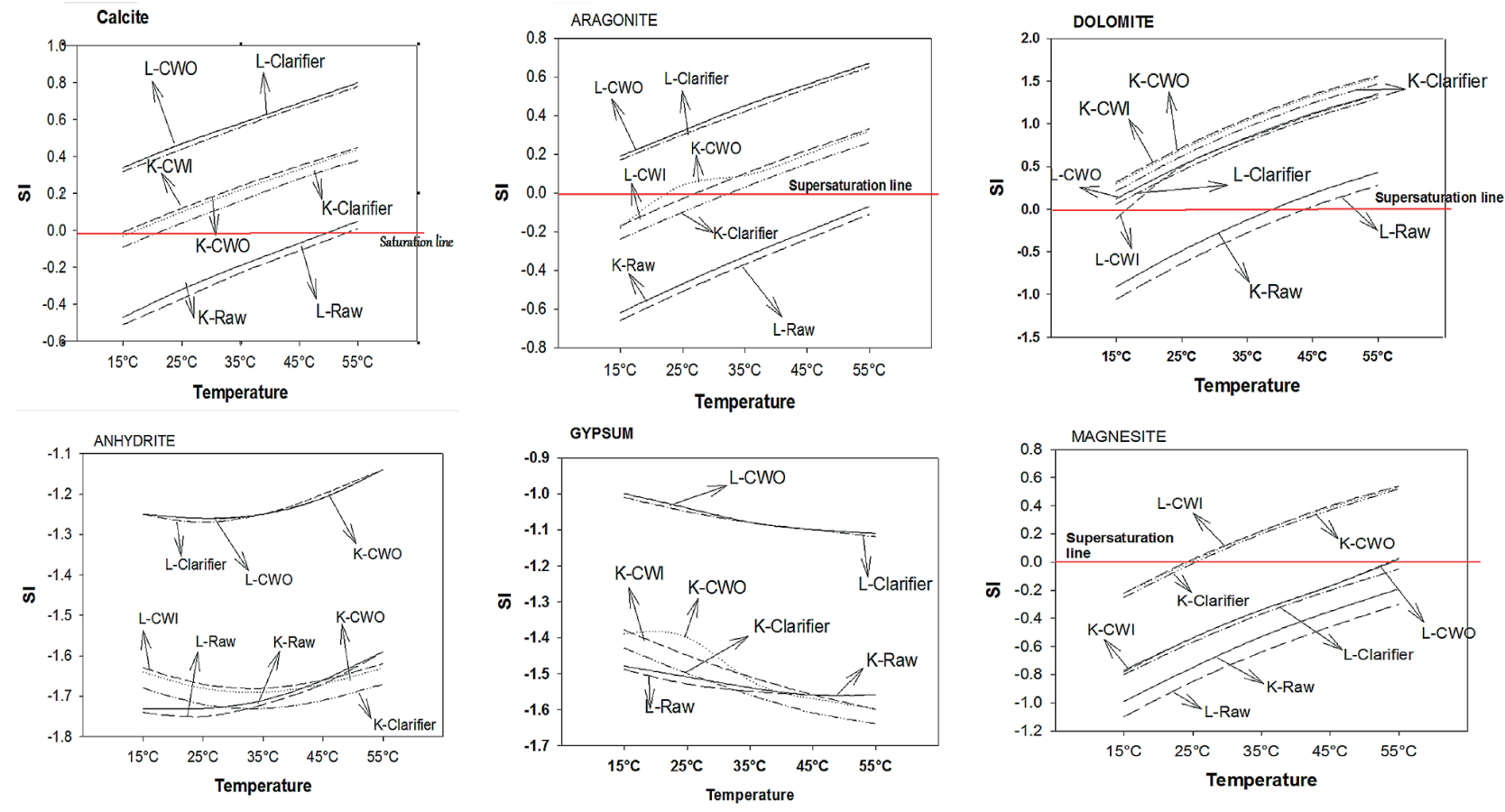

Figure 8

Predictive saturation indices of mineral assemblages based on temperature, viz, calcite, aragonite, dolomite, anhydrite, gypsum and magnesite (K and $L$ represent water drawn from Kriel and Lethabo, respectively) 
gypsum). The saturation indices of minerals were calculated from the F_H.DAT. Calcite $\left(\mathrm{CaCO}_{3}\right)$ was found to have higher saturation indices than aragonite $\left(\mathrm{CaCO}_{3}\right)$. For example, in almost all (except raw water samples) calcite showed supersaturation at lower temperatures than aragonite. A very specific illustration is the precipitation of calcite and aragonite in the Kriel clarifier (K-clarifier) and Kriel cooling water outlet (K-CWO), from $15^{\circ} \mathrm{C}$ and $30^{\circ} \mathrm{C}$, respectively (Fig. 8 Calcite, and Fig. 8 Aragonite). It is important to mention that crystals of $\mathrm{CaCO}_{3}$ exist in different polymorphs, i.e., calcite, aragonite and vaterite. Calcite is the most stable of the three while vaterite is the least stable. Ideally, they form under different conditions, for the same amounts of inputs (Wada et al., 2013). Aragonite is a high-pressure phase which changes to calcite at ambient conditions. Its precipitation is dependent on $\mathrm{pH}$, temperature, super-saturation and $\mathrm{CO}_{2}$ content.

The relatively high degree of under-saturation of gypsum $\left(\mathrm{CaSO}_{4} \cdot 2 \mathrm{H}_{2} \mathrm{O}\right)$ and anhydrite form $\left(\mathrm{CaSO}_{4}\right)$ compared to other mineral phases is likely to be due to the low concentration of sulphate ions in the cooling and raw water samples (Fig. 8 gypsum; Fig. 8 anhydrite). Gypsum and anhydrite dissolution were apparent in most of the water samples, thus contributing free $\mathrm{Ca}^{2+}$ that enhances calcite precipitation, a phenomenon called common ion driven precipitation (CIDP). We noted that calcium concentrations are controlled by calcite and aragonite dissolution. Furthermore, the dynamics of $\mathrm{Ca}$ complexation and dissolution govern its $\mathrm{pH}$-dependent equilibria (Pokrovsky et al., 2009). Pokrovsky et al. (2009) provided a detailed argument on the dissolution kinetics and precipitation of dolomite and magnesite, in addition to calcite, as a function of $\mathrm{pH}$, temperature and pressure. They noted that the rate constants of dissolution of these minerals increase with increase in $\mathrm{pH}$ and temperature. This agrees with the temperature-dependent simulation results in this study.

\section{Speciation simulations based on NOM (fulvic acid)}

The concentrations of fulvic acid were determined to be in the range 3.5 to $81.5 \mathrm{mg} \cdot \mathrm{L}^{-1}$, viz, (i)) Lethabo had concentrations as follows: raw $4.022 \mathrm{mg} \cdot \mathrm{L}^{-1}$, clarifier $45.902 \mathrm{mg} \cdot \mathrm{L}^{-1}$, CWI 25.830 $\mathrm{mg} \cdot \mathrm{L}^{-1}$ and CWO $38.775 \mathrm{mg} \cdot \mathrm{L}^{-1}$, compared to (ii) Kriel's raw $5.934 \mathrm{mg} \cdot \mathrm{L}^{-1}$, clarifier $81.422 \mathrm{mg} \cdot \mathrm{L}^{-1}$, CWI $47.023 \mathrm{mg} \cdot \mathrm{L}^{-1}$ and

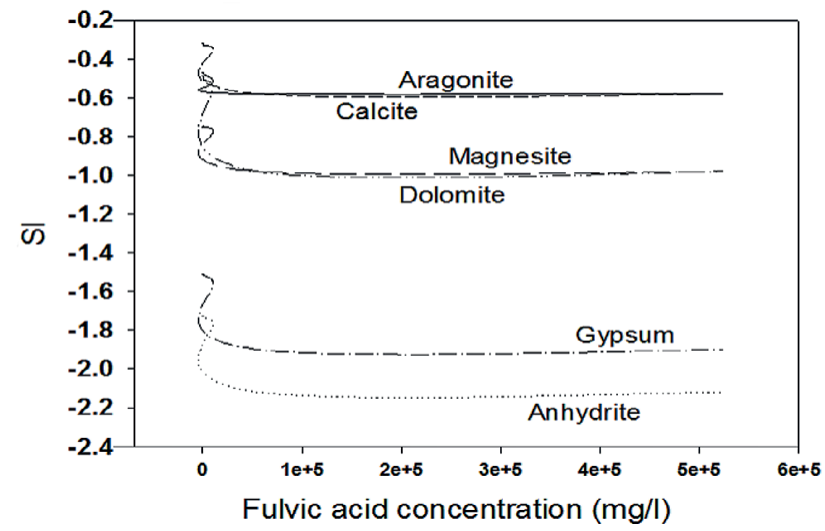

Figure 9

Extrapolated mineral phase curves based on raw water concentrations at Kriel. Various exponents of the experimental fulvic acid concentrations were input parameters into the PHREEQC SOLUTION SPECIES using the F_H.DAT.
CWO $49.290 \mathrm{mg} \cdot \mathrm{L}^{-1}$ (Table 3). Raw water fulvics were compared with those from the clarifier as well as those from the cooling water tower. As expected, the results showed that the fulvics from the cooling tower were found to be less than a tenth of those from the clarifier. This may be attributed to the fact that recycled water volumes keep decreasing due to the evaporative processes in the cooling water chambers and this concentrates the humic substances (Pather, 2004). Various exponents of the experimental fulvic acid concentrations were inputted to the PHREEQC SOLUTION_SPECIES using the F_H.DAT and the results are presented in Figs 9 and 10.

How available and reliable are the thermodynamic and equilibrium definitions of NOM in the existing databases? Undoubtedly, no single modification would suit all organic compounds. Huber et al. (2012) agree with this. In their simulations, they chose to pick thermodynamic definitions of volatile fatty acids (acetate, propionate, butyrate and lactate) from MINTEQ.V4.DAT and included them in the PHREEQC code with interactive interface (PHREEQCI) database (Huber et al., 2012). Therefore, to answer the question, the F_H.DAT was constructed using available thermodynamic definitions for the $\mathrm{Ca}$ and Mg-fulvate equilibrium phases in Visual MINTEQ.v3.1.1. This work drew up specific species-oriented modifications on the premise that variability of both the physico-chemical conditions and the wide range of compounds in cooling water play a critical role in data generation.

Based on the expanded fulvic acid simulations from our study, the effect of fulvate ions as defined in the EQUILIBRIUM_PHASE and SOLUTION_MASTER_SPECIES in the F_H.DAT was investigated. Results show that by changing the fulvic acid concentrations in cooling water processes, one can alter scaling indices of mineral phases significantly (Figs 9 and 10). These figures are extracts of the raw and cooling water results at Kriel power station. This reduction may be attributed to the formation of the defined complexes between $\mathrm{Ca} / \mathrm{Mg}$ and fulvic acid, viz, MgFulvate and CaFulvate.

\section{Scale control modelling studies}

In this article, the composition of scale in pipes, with physicochemical conditions determined, is given in Table 4 . The experimental results shown in Table 4 were obtained from

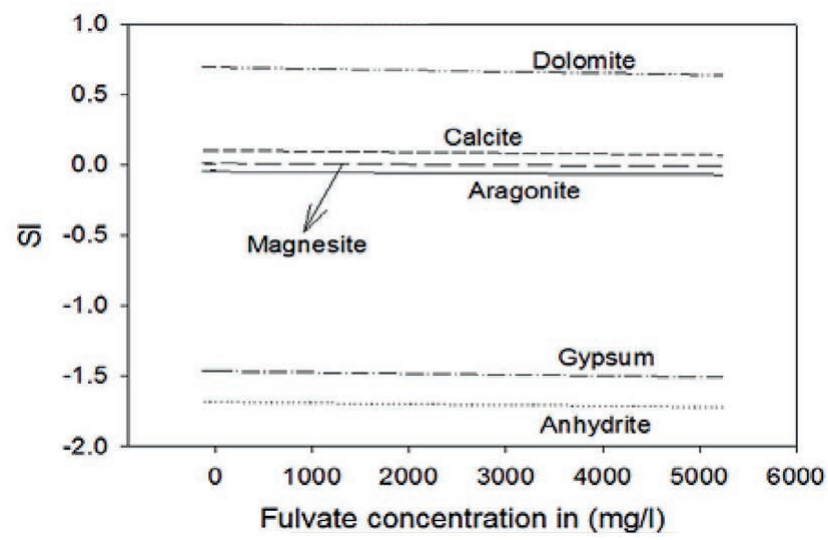

Figure 10

Extrapolated mineral phase curves on a reduced scale on $x$-axis showing the concentration of fulvic acid $\left(0-6000 \mathrm{mg} \cdot \mathrm{L}^{-1}\right)$ 
analysis of a scale sample obtained from cooling water pipes at Lethabo. Accordingly, the results showed varied concentrations of elements in the order of $\mathrm{Zn}>\mathrm{Al}>\mathrm{Ca}>\mathrm{Mg}$ for the 4 metal ions under consideration.

The second step was to accurately determine the content of scaling metals and other trace elements in water. The fundamental objective in the current context is to keep $\mathrm{Ca} / \mathrm{Mg}$ ions in solution (complexed form). Therefore, it was important to include organic compounds in the PHREEQC databases and simulate scale formation under different conditions (shown in the methodology section). In that section, a typical illustration

\begin{tabular}{|c|c|c|c|}
\hline \multicolumn{4}{|c|}{$\begin{array}{c}\text { TABLE } 4 \\
\begin{array}{c}\text { Selected sample XRF results of the components of scale } \\
\text { obtained from Lethabo cooling water pipes }\end{array}\end{array}$} \\
\hline Mineral phase & Formula & $\%$ by mass & Total \\
\hline \multicolumn{4}{|l|}{ Zn mineral phases } \\
\hline Smithsonite & $\mathrm{Zn}\left(\mathrm{CO}_{3}\right)$ & 0.4 & 48.5 \\
\hline Zinc phosphate & $\mathrm{Zn}\left(\mathrm{PO}_{3}\right)_{2}$ & 28.3 & \\
\hline Zinkosite, syn & $\mathrm{ZnSO}_{4}$ & 19.8 & \\
\hline \multicolumn{4}{|l|}{ Al mineral phases } \\
\hline $\begin{array}{l}\text { Berlinite; berlinite, } \\
\text { syn }\end{array}$ & $\mathrm{Al}\left(\mathrm{PO}_{4}\right)$ & 35.6 & 36.9 \\
\hline Diaspore, syn & $\mathrm{AlO}(\mathrm{OH})$ & 1.3 & \\
\hline \multicolumn{4}{|l|}{ Ca mineral phases } \\
\hline $\begin{array}{l}\text { Calcium iron(II) } \\
\text { oxide }\end{array}$ & $\mathrm{CaFeO}_{2}$ & 5.5 & 14.1 \\
\hline Gypsum & $\mathrm{CaSO}_{4} \cdot 2 \mathrm{H}_{2} \mathrm{O}$ & 0.6 & \\
\hline Calcium silicide & $\mathrm{CaSi}_{2}$ & 0.3 & \\
\hline Aragonite & $\mathrm{Ca}\left(\mathrm{CO}_{3}\right)$ & 7.5 & \\
\hline Dolomite & $\mathrm{Ca} \mathrm{Mg}\left(\mathrm{CO}_{3}\right)_{2}$ & 0.2 & \\
\hline \multicolumn{4}{|l|}{ Mg mineral phases } \\
\hline Magnesite, syn & $\mathrm{Mg}\left(\mathrm{CO}_{3}\right)$ & 0.5 & 0.7 \\
\hline Dolomite & $\mathrm{Ca} \mathrm{Mg}\left(\mathrm{CO}_{3}\right)_{2}$ & 0.2 & \\
\hline
\end{tabular}

of precipitative and complexation processes has been discussed using the context of fulvic acid interactions with metal cations.

Table 5 shows potential scaling potentials of selected mineral phases of $\mathrm{Ca}$ and $\mathrm{Mg}$ in water; aragonite $\left(\mathrm{CaCO}_{3}\right)$, artinite $\left(\mathrm{MgCO}_{3}: \mathrm{Mg}(\mathrm{OH})_{2}: 3 \mathrm{H}_{2} \mathrm{O}\right)$, brucite $\left(\mathrm{Mg}(\mathrm{OH})_{2}\right)$, calcite $\left(\mathrm{CaCO}_{3}\right)$, dolomite $\left(\mathrm{CaMg}\left(\mathrm{CO}_{3}\right)_{2}\right)$, dolomite $(\mathrm{d})$ $\mathrm{CaMg}\left(\mathrm{CO}_{3}\right)_{2}$, huntite $\left(\mathrm{CaMg}_{3}\left(\mathrm{CO}_{3}\right)_{4}\right)$, hydromagnesite $\left(\mathrm{Mg}_{5}\left(\mathrm{CO}_{3}\right)_{4}(\mathrm{OH})_{2}: 4 \mathrm{H}_{2} \mathrm{O}\right)$ and magnesite $\left(\mathrm{MgCO}_{3}\right)$. From this study, the interaction between calcium and carbonate ions is defined to influence scaling in water pipes. The saturation indices of aragonite and calcite (polymorphs of $\mathrm{CaCO}_{3}$ ) are positive throughout the recycle water processes (in raw and in cooling water). From the study, these polymorphs remained relatively stable throughout the recycle processes.

The third step is to consider the current state Ca binding to fulvic acid, in raw water compared to recycled cooling water. For instance, the molality values of CaFulvate are lower (viz; $4.6 \times 10^{-13}$ and $1.5 \times 10^{-11}$ ) in raw water at Lethabo and Kriel, respectively. This complex is 100 -fold higher in cooling water than in raw water (Table 6). A similar scenario is experienced with MgFulvate. This phenomenon explains the fact that cooling recycled volumes have reduced precipitation potentials for $\mathrm{Mg}$ and $\mathrm{Ca}$. This leads to the conclusion that manipulation of physicochemical parameters enhances complexation of $\mathrm{Ca}$ and $\mathrm{Mg}$, which inhibits complexation of non-scaling metals while reducing the components that oxidise, which is critical in scale control.

\section{TABLE 6}

Summary of the $\mathrm{Ca} / \mathrm{Mg}$ fulvate complexes (in mols) in raw and cooling water

\begin{tabular}{|l|c|c|c|c|}
\hline & \multicolumn{2}{|c|}{ Lethabo station } & \multicolumn{2}{c|}{ Kriel station } \\
\hline $\begin{array}{l}\text { Complexed } \\
\text { species }\end{array}$ & Raw water & $\begin{array}{c}\text { Cooling } \\
\text { water }\end{array}$ & Raw water & $\begin{array}{c}\text { Cooling } \\
\text { water }\end{array}$ \\
\hline Fulvate-2 & $5.5 \quad 10^{-6}$ & $5.0 \times 10^{-5}$ & $8.1 \times 10^{-6}$ & $1.1 \times 10^{-4}$ \\
\hline HFulvate- & $5.3 \times 10^{-11}$ & $7.4 \times 10^{-10}$ & $1.5 \times 10^{-11}$ & $2.8 \times 10^{-10}$ \\
\hline CaFulvate & $4.6 \times 10^{-13}$ & $1.4 \times 10^{-11}$ & $1.1 \times 10^{-12}$ & $1.3 \times 10^{-10}$ \\
\hline MgFulvate & $6.7 \times 10^{-12}$ & $6.1 \times 10^{-10}$ & $1.2 \times 10^{-11}$ & $6.8 \times 10^{-10}$ \\
\hline
\end{tabular}

\begin{tabular}{|c|c|c|c|c|}
\hline \multicolumn{5}{|c|}{$\begin{array}{c}\text { TABLE } 5 \\
\text { Saturation indices of various mineral phases of } \mathrm{Ca} \text { and } \mathrm{Mg}\end{array}$} \\
\hline & \multicolumn{2}{|c|}{ Lethabo station } & \multicolumn{2}{|c|}{ Kriel station } \\
\hline & \multicolumn{4}{|c|}{ Saturation indices } \\
\hline Mineral phase & Raw water & Cooling water & Raw water & Cooling water \\
\hline Anhydrite $\left(\mathrm{CaSO}_{4}\right)$ & -5.8 & -3.6 & -5.3 & -3.2 \\
\hline Aragonite $\left(\mathrm{CaCO}_{3}\right)$ & 0.9 & 0.7 & 1.0 & 1.8 \\
\hline Artinite $\left(\mathrm{MgCO}_{3}: \mathrm{Mg}(\mathrm{OH})_{2}: 3 \mathrm{H}_{2} \mathrm{O}\right)$ & 0.6 & -0.6 & 0.1 & 0.8 \\
\hline Brucite $\left(\mathrm{Mg}(\mathrm{OH})_{2}\right)$ & 0.2 & -1.3 & -0.2 & -0.1 \\
\hline Calcite $\left(\mathrm{CaCO}_{3}\right)$ & 1.1 & 0.9 & 1.1 & 2.0 \\
\hline Dolomite $\left(\mathrm{CaMg}\left(\mathrm{CO}_{3}\right)_{2}\right)$ & 2.8 & 2.9 & 2.8 & 4.2 \\
\hline Dolomite(d) $\mathrm{CaMg}\left(\mathrm{CO}_{3}\right)_{2}$ & 2.3 & 2.4 & 2.3 & 3.6 \\
\hline Epsomite $\left(\mathrm{MgSO}_{4}: 7 \mathrm{H}_{2} \mathrm{O}\right)$ & -7.5 & -4.8 & -7.0 & -5.4 \\
\hline Gypsum $\left(\mathrm{CaSO}_{4}: 2 \mathrm{H}_{2} \mathrm{O}\right)$ & -5.6 & -3.4 & -5.0 & -3.0 \\
\hline Huntite $\left(\mathrm{CaMg}_{3}\left(\mathrm{CO}_{3}\right)_{4}\right)$ & 2.0 & 2.6 & 1.9 & 4.3 \\
\hline Magnesite $\left(\mathrm{MgCO}_{3}\right)$ & 1.2 & 1.5 & 1.1 & 1.6 \\
\hline Nesquehonite $\left(\mathrm{MgCO}_{3}: 3 \mathrm{H}_{2} \mathrm{O}\right)$ & -1.2 & -0.9 & -1.3 & -0.8 \\
\hline Portlandite $\left(\mathrm{Ca}(\mathrm{OH})_{2}\right)$ & -6.3 & -8.3 & -6.6 & -6.1 \\
\hline
\end{tabular}


Given the results in Tables 5 and 6, we can conclude that complexation between $\mathrm{Ca} / \mathrm{Mg}$ cations and fulvates could be linked to saturation indices in explaining the scaling potential. Saturation index results show that only the values in raw water samples are slightly different. However, the fact is that the incorporation of the equilibrium equations for $\mathrm{Ca}$ and $\mathrm{Mg}$ with fulvates into the PHREEQC databases, could offer a special link that explains simultaneous complexation and precipitation reactions in fresh waters used for industrial purposes. Modelling the formation of these discrete chemical complexes showed a reduction in the concentration of free $\mathrm{Ca}$ and $\mathrm{Mg}$ ions in solution, hence decreased scaling potential. In addition, the study has shown that the concentrations of fulvic acid and temperatures may be manipulated, and using the geochemical code PHREEQC, the incidence of scaling could be predicted and controlled.

\section{CONCLUSIONS}

The HS-diagram revealed the predominance of the fulvic acid fraction of NOM in raw and cooling water. For all samples, the fulvic acid fraction did not differ significantly relative to total dissolved organic carbon. In addition, the spectral EEM signatures, showed intense activity of $\mathrm{HS}$ at $\boldsymbol{\lambda}_{\mathrm{EX}} 250-290 / \boldsymbol{\lambda}_{\mathrm{EM}}$ $350-500 \mathrm{~nm}$, which confirmed the predominance of fulvic acid in NOM. Using the PHREEQC code, the Tipping and Hurley database (T_H.DAT) was successfully modified by including $\mathrm{Mg}$ and $\mathrm{Ca}$ complexation equilibrium equations with the fulvate ion. This was achieved by incorporating Fulvate-2 complexation equilibria in the SOLUTION_MASTER_SPECIES block and defining it as SOLUTION_SPECIES. Both the humates and fulvates were incorporated in the T_H.DAT database correctly and were able to generate outputs on the PHREEQC code. As a result, new complexation the $\mathrm{Ca}$-fulvate and $\mathrm{Mg}$-fulvate mineral phase outputs were obtained and related to the scaling potential of $\mathrm{Ca}$ / $\mathrm{Mg}$. Overall, the entire study has shown that if the concentrations of organics (such as fulvic acid) are known, the conditions that favour their complexation with $\mathrm{Ca} / \mathrm{Mg}$ could be manipulated appropriately to control the incidence of scaling in pipe circuitry.

\section{ACKNOWLEDGEMENTS}

The authors of this paper are grateful to the Centre for Nanomaterials Science Research and the Faculty of Science which hosts the Department of Applied Chemistry at the University of Johannesburg. Many thanks to David Parkhurst of the USGS for providing the authors with valuable information on the PHREEQC code.

\section{REFERENCES}

AHMED AM, HAMILTON-TAYLOR J, BIEROZA M, ZHANG H and DAVISON W (2014) Improving and testing geochemical speciation predictions of metal ions in natural waters. Water Res. 67 276-291. https://doi.org/10.1016/j.watres.2014.09.004

BRUNNER G (2014) Chapter 3 - Properties of mixtures with water. In: Gerd B (ed.) Supercritical Fluid Science and Technology. Elsevier, Amsterdam.

CHARLTON S and PARKHURST D (2011) Modules based on the geochemical model PHREEQC for use in scripting and programming languages. Comput. Geosci. 37 1653-1663. https:// doi.org/10.1016/j.cageo.2011.02.005

CHRISTENSEN J, TIPPING E, KINNIBURGH D, GRØN C and CHRISTENSEN TH (1998) Proton binding by groundwater fulvic acids of different age, origins, and structure modeled with the model V and NICA-Donnan model. Environ. Sci. Technol. 32 3346-3355. https://doi.org/10.1021/es971134o
FILLOUX E, GALLARD H and CROUE J (2012) Identification of effluent organic matter fractions responsible for low-pressure membrane fouling. Water Res. 46 5531-5540. https://doi. org/10.1016/j.watres.2012.07.034

GENTRY-SHIELDS J, WANG A, CORY RM and STEWART JR (2013) Determination of specific types and relative levels of QPCR inhibitors in environmental water samples using excitationemission matrix spectroscopy and PARAFAC. Water Res. 47 3467-3476. https://doi.org/10.1016/j.watres.2013.03.049

GILMORE A, LARKUM A, SALIH A, ITOH S, SHIBATA Y, BENA C and VAN WOESIK R (2003) Simultaneous time resolution of the emission spectra of fluorescent proteins and zooxanthellar chlorophyll in reef building corals. Photochem. Photobiol. 77 515-523. https://doi. org/10.1562/0031-8655(2003)077<0515:STROTE >2.0.CO;2

GUÉGUEN C, GRANSKOG MA, MCCULLOUGH G and BARBER DG (2011) Characterisation of colored dissolved organic matter in Hudson Bay and Hudson Strait using parallel factor analysis. J. Mar. Syst. 88 423-433. https://doi.org/10.1016/j.jmarsys.2010.12.001

GUO X, HE X, ZHANG H, DENG Y, CHEN L and JIANG J (2012) Characterization of dissolved organic matter extracted from fermentation effluent of swine manure slurry using spectroscopic techniques and parallel factor analysis (PARAFAC). Microchem. J. 102 115-122. https://doi.org/10.1016/j.microc.2011.12.006

GUSTAFSSON JP (2001) Modeling the acid-base properties and metal complexation of humic substances with the Stockholm Humic Model. J. Coll. Interf. Sci. 244 102-112. https://doi.org/10.1006/ jcis. 2001.7871

GUSTAFSSON JP and BERGGREN KD (2005) Modeling saltdependent proton binding by organic soils with the NICA-Donnan and Stockholm Humic models. Environ. Sci. Technol. 39 5372-5377. https://doi.org/10.1021/es0503332

HOCH A, REDDY M and AIKEN G (2000) Calcite crystal growth inhibition by humic substances with emphasis on hydrophobic acids from the Florida Everglades. Geochim. Cosmochim. Acta 64 61-72. https://doi.org/10.1016/S0016-7037(99)00179-9

HUBER P, NIVELON S, OTTENIO P and NORTIER P (2012) Coupling a chemical reaction engine with a mass flow balance process simulation for scaling management in papermaking process waters. Ind. Eng. Chem. Res. 52 421-429. https://doi. org/10.1021/ie300984y

HUBER SA, BALZ A, ABERT M and PRONK W (2011)

Characterisation of aquatic humic and non-humic matter with size-exclusion chromatography-organic carbon detection-organic nitrogen detection (LC-OCD-OND). Water Res. 45 879-885. https://doi.org/10.1016/j.watres.2010.09.023

KOOPAL LK, SAITO T, PINHEIRO JP and VAN RIEMSDIJK WH (2005) Ion binding to natural organic matter: General considerations and the NICA-Donnan model. Coll. Surf. A: Physicochem. Eng. Aspects 265 40-54. https://doi.org/10.1016/j. colsurfa.2004.11.050

MILNE C, KINNIBURGH D, VAN RIEMSDIJK W and TIPPING E (2003) Generic NICA-Donnan model parameters for metal-ion binding by humic substances. Environ. Sci. Technol. 37 958-971. https://doi.org/10.1021/es0258879

PARKHURST D and APPELO C (2013) Description of input and examples for PHREEQC version 3: a computer program for speciation, batch-reaction, one-dimensional transport, and inverse geochemical calculations. US Geological Survey, Reston, Virginia.

PATHER V (2004) Eskom and water. Proc. 2004 Water Institute of Southern Africa (WISA) Biennial Conference, 26 May 2004, Cape Town, South Africa. URL: http://www.ewisa.co.za/literature/ files/260.pdf (Accessed October 2014).

PETERS C (2009) Accessibilities of reactive minerals in consolidated sedimentary rock: An imaging study of three sandstones. Chem. Geol. 265 198-208. https://doi.org/10.1016/j.chemgeo.2008.11.014

POKROVSKY O, GOLUBEV S, SCHOTT J and CASTILLO A (2009) Calcite, dolomite and magnesite dissolution kinetics in aqueous solutions at acid to circumneutral $\mathrm{pH}, 25$ to $150^{\circ} \mathrm{C}$ and 1 to 55 atm: New constraints on $\mathrm{CO}_{2}$ sequestration in sedimentary basins. Chem. Geol. 265 20-32. https://doi.org/10.1016/j. chemgeo.2009.01.013

POURRET O, DAVRANCHE M, GRUAU G and DIA A (2007) 
Organic complexation of rare earth elements in natural waters: evaluating model calculations from ultrafiltration data. Geochim. Cosmochim. Acta 71 2718-2735. https://doi.org/10.1016/j. gca.2007.04.001

ROSENBERG YO, REZNIK I J, ZMORA-NAHUM S and GANOR J (2012) The effect of $\mathrm{pH}$ on the formation of a gypsum scale in the presence of a phosphonate antiscalant. Desalination 284 207-220. https://doi.org/10.1016/j.desal.2011.08.061

TIPPING E (2002) Cation Binding by Humic Substances. Cambridge University Press, Cambridge, England. https://doi.org/10.1017/ CBO9780511535598

WADA N, HORIUCHI N, NAKAMURA M, HIYAMA T, NAGAI A and YAMASHITA K (2013) Effect of poly (acrylic acid) and polarization on the controlled crystallization of calcium carbonate on single-phase calcite substrates. Crystal Growth Design 13 2928-2937. https://doi.org/10.1021/cg400337m

ZHANG F, YAN C, TENG HH, RODEN EE and XU H (2013) In situ AFM observations of $\mathrm{Ca}-\mathrm{Mg}$ carbonate crystallization catalyzed by dissolved sulfide: Implications for sedimentary dolomite formation. Geochim. Cosmochim. Acta 105 44-55. https://doi.org/10.1016/j. gca.2012.11.010

ZHOU S, SHAO Y, GAO N, LI L, DENG J, TAN C and ZHU M (2014) Influence of hydrophobic/hydrophilic fractions of extracellular organic matters of Microcystis aeruginosa on ultrafiltration membrane fouling. Sci. Total Environ. 471 201-207. https://doi. org/10.1016/j.scitotenv.2013.09.052 